\title{
Myxosporean vegetative stages in the choroidal rete mirabile of Gasterosteus aculeatus infected with Myxobilatus gasterostei and Sphaerospora elegans
}

\author{
J. Lom ${ }^{1}$, A. W. Pike ${ }^{2}$, S. W. Feist ${ }^{3}$ \\ ${ }^{1}$ Czech Academy of Sciences, Institute of Parasitology, Branišovská 31, 37005 Česke Budĕjovice, Czechoslovakia \\ ${ }^{2}$ Department of Zoology, University of Aberdeen, Aberdeen AB9 2TN, Scotland \\ ${ }^{3}$ Ministry of Agriculture, Fisheries and Food, Fish Diseases Laboratory, Weymouth, Dorset DT4 8UB, England
}

\begin{abstract}
Examination of samples of three-spined sticklebacks Gasterosteus aculeatus from Loch Flemington in Scotland and from 3 sites in southern England revealed hitherto unknown myxosporean stages in the choroidal rete mirabile of the eye. This paper describes the light and ultrastructural features of these stages and discusses affinities with PKX and extrasporogonic stages of other myxosporean parasites, particularly those belonging to the genus Sphaerospora.
\end{abstract}

\section{INTRODUCTION}

Since the discovery (Csaba 1976) and correct interpretation (Bucsek \& Csaba 1981, Lom et al. 1983, Csaba et al. 1984) of the proliferative blood-stream stages of Sphaerospora renicola Dyková \& Lom, 1982, similar blood-stream stages have been found in 19 other species of the genus Sphaerospora (Lom et al. 1985, Baska \& Molnar 1988, Hedrick et al. 1988, Kepr \& Trsová 1989). Extrasporogonic stages of $S$. renicola were also found in other sites in the swimbladder (Kovacs-Gayer et al. 1982, Körting 1982), and in the epithelial cells of renal tubules (Lom \& Dyková 1985). Similar extrasporogonic stages have been found in Myxidium lieberkuehni (Lom et al. 1989). Their exist- ence may therefore be widespread in Sphaerospora and other myxosporean genera.

An investigation of myxosporidiosis in the threespined stickleback Gasterosteus aculeatus initially revealed hitherto unknown myxosporean stages in the capillaries of the choroidal rete mirabile ('choroidal gland') of the eye, and subsequently also in the swimbladder rete. This paper presents the results of the study, and discusses affinities with PKX and extrasporogonic stages of other myxosporean parasites.

\section{MATERIAL AND METHODS}

Sticklebacks were collected from Loch Flemington, Scotland $\left(57^{\circ} 32^{\prime} N, 3^{\circ} 58^{\prime} \mathrm{W}\right)$, and from sites in the

Table 1. Gasterosteus aculeatus. Examination of sticklebacks from the south of England for choroidal rete vegetative stages of myxosporeans

\begin{tabular}{lcccc|}
\hline Source & $\begin{array}{c}\text { No. } \\
\text { examined }\end{array}$ & $\begin{array}{c}\text { \% Prevalence } \\
\text { Sphaerospora } \\
\text { elegans }\end{array}$ & $\begin{array}{c}\text { Myxobilatus } \\
\text { gasterostei }\end{array}$ & $\begin{array}{c}\text { Choroidal rete } \\
\text { stages }\end{array}$ \\
\hline R. Avon & 17 & 100 & 100 & 29 \\
R. Weaver & 50 & 40 & 0 & 0 \\
R. Hooke & 15 & 35 & 6.6 & 6.6 \\
\hline
\end{tabular}


south of England, namely the River Avon (Wiltshire) $\left(51^{\circ} 01^{\prime} \mathrm{N}, 01^{\circ} 45^{\prime} \mathrm{W}\right.$ ), River Weaver (Devon) (50 $51^{\prime} \mathrm{N}$, $03^{\circ} 19^{\prime} \mathrm{W}$ ) and River Hooke (Dorset) $\left(50^{\circ} 48^{\prime} \mathrm{N}\right.$, $02^{\circ} 39^{\prime} \mathrm{W}$ ). Fish were maintained in laboratory aquaria with a constant supply of aerated and dechlorinated water. Fish were autopsied soon after return to the laboratory and at intervals thereafter. Tissues were fixed in $10 \%$ neutral buffered formalin and routinely processed to paraffin wax or resin sections.

Smear preparations of the choroidal rete were stained with Giemsa and samples of the rete were prepared for electron microscopy. They were fixed in $2 \%$ glutaraldehyde in $0.1 \mathrm{M}$ cacodylate buffer, postfixed in $2 \%$ osmic acid in the same buffer and embedded in Spurr resin. Ultrathin sections were stained with uranyl acetate and lead citrate and examined with a Philips 301 electron microscope at $80 \mathrm{kV}$ accelerating voltage

\section{RESULTS}

The sticklebacks from Loch Flemington were heavily infected with a variety of protozoan parasites: Glugea anomala (prevalence $25 \%$ ), Goussia gasterostei $(40 \%$ ), Myxobilatus gasterostei (100\%), and Sphaerospora elegans (83\%). Myxosporean vegetative stages in the capillaries of the choroidal rete were detected in fresh mounts in $25 \%$ of the sample; the intensity of infection was sometimes high, so that they could easily be found. The stages were seen, in a small number of cases, in the swimbladder rete mirabile. Data from fish from sites in England are given in Table 1.

When examining a fresh mount, the stages could be distinguished as round or ellipsoidal bodies (Fig. 1) lying in the capillaries of the rete. They were 8 to $22 \mu \mathrm{m}$ in diameter and appeared to have structureless peripheral cytoplasm containing several inner bodies and a few refractile granules. They were non-motile seeming to adhere quite firmly to the surface of the endothelial cells so that they are not dislodged when preparing a smear. This is probably why they are difficult to detect in Giemsa-stained impression smears.

Ultrastructurally, the choroidal rete stages ranged from small spherical primary cells with one secondary cell which left enough space (Fig. 2) or insufficient space (Fig. 3) for the red blood corpuscles to pass by, to large primary cells with numerous internal cells which completely occluded the capillary possibly preventing blood circulation through that capillary (Fig. 4). Most of the sectioned primary cells included 1 to 5 secondary cells; exceptionally, 9 or 10 and once even 18 secondary cells could be seen in the section. In some primary cells, one of the secondary cells, but not more, harboured 1 or 2 tertiary cells. Tertiary cells could be seen even in primary cells with just 1 secondary cell Although counts of the number of cells contained within 1 primary cell cannot be exact from thin sections, they nevertheless give some indication of the approximate structure of the primary cell.

The primary cells adhered to the endothelial cell membranes leaving gaps of 35 to $50 \mathrm{~nm}$ (Fig. 5). Sometimes the gap was wide and filled by a moderately opaque substance (Fig. 5). There were no hemidesmosome-like junctional complexes on either side of the host-parasite boundary. The primary cells sometimes had surface projections, interlocking with the endothelial cell surface.

The primary cells had a thin, finely granular, homogeneous ectoplasmic layer. and their rytnplasm contained various vesicles of different sizes, mostly vacuole-like (Figs. $7 \& 8$ ) sometimes with more or less electron-opaque amorphous substance, mitochondria, one to several Golgi, sparse cisternae of endoplasmic reticulum and some free ribosomes.

Secondary cells seen in section ranged from presumably young ones, with a small volume of lucent endoplasm, a few mitochondria and vesicles, to presumably mature ones, with denser cytoplasm and a variety of cytoplasmic organelles including typical Golgi, bundles of microtubules which were either typically straight (Fig. 6) or arched, and sometimes with plentiful free ribosomes and other inclusions. The contents of all cell inclusions may vary depending on the stage of secondary cell development. The cell surface may be raised into short projections. Secondary cells were either isolated in the primary cell cytoplasm, or lay together, in groups of 2 to 5 , in a common membrane, indicating previous divisions within this 'vacuole'. In some secondary cells, there were 2 nuclei or a possibility of a forming partition (Fig. 8), representing secondary cell division.

Tertiary cells always resembled young secondary cells. Most of their volume was occupied by a nucleus leaving a thin layer of electron-lucent cytoplasm beneath the cell membrane. The cytoplasm only contained 1 mitochondrion in the section and no other organelles (Fig. 7)

In many primary cells, empty spaces containing an unstructured mass of cytoplasm indicated where one of the secondary cells had died.

\section{DISCUSSION}

The organism from the choroidal or swimbladder rete certainly represents a stage in an extrasporogonic sequence of a myxosporean developmental cycle. An extra-sporogonic stage may be defined (Lom 1987) as one that proliferates, without spore formation, prior to 

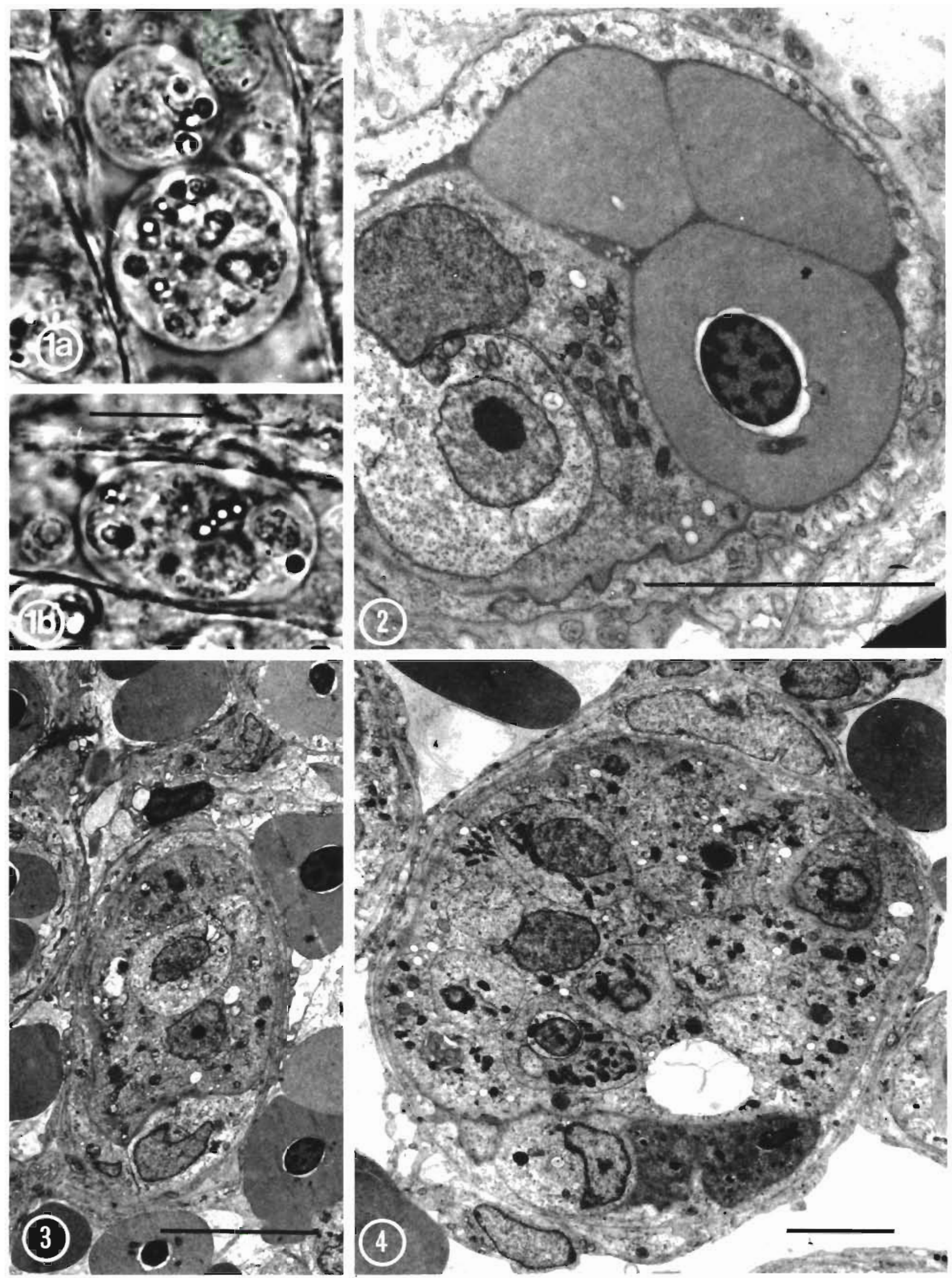

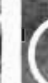

. 

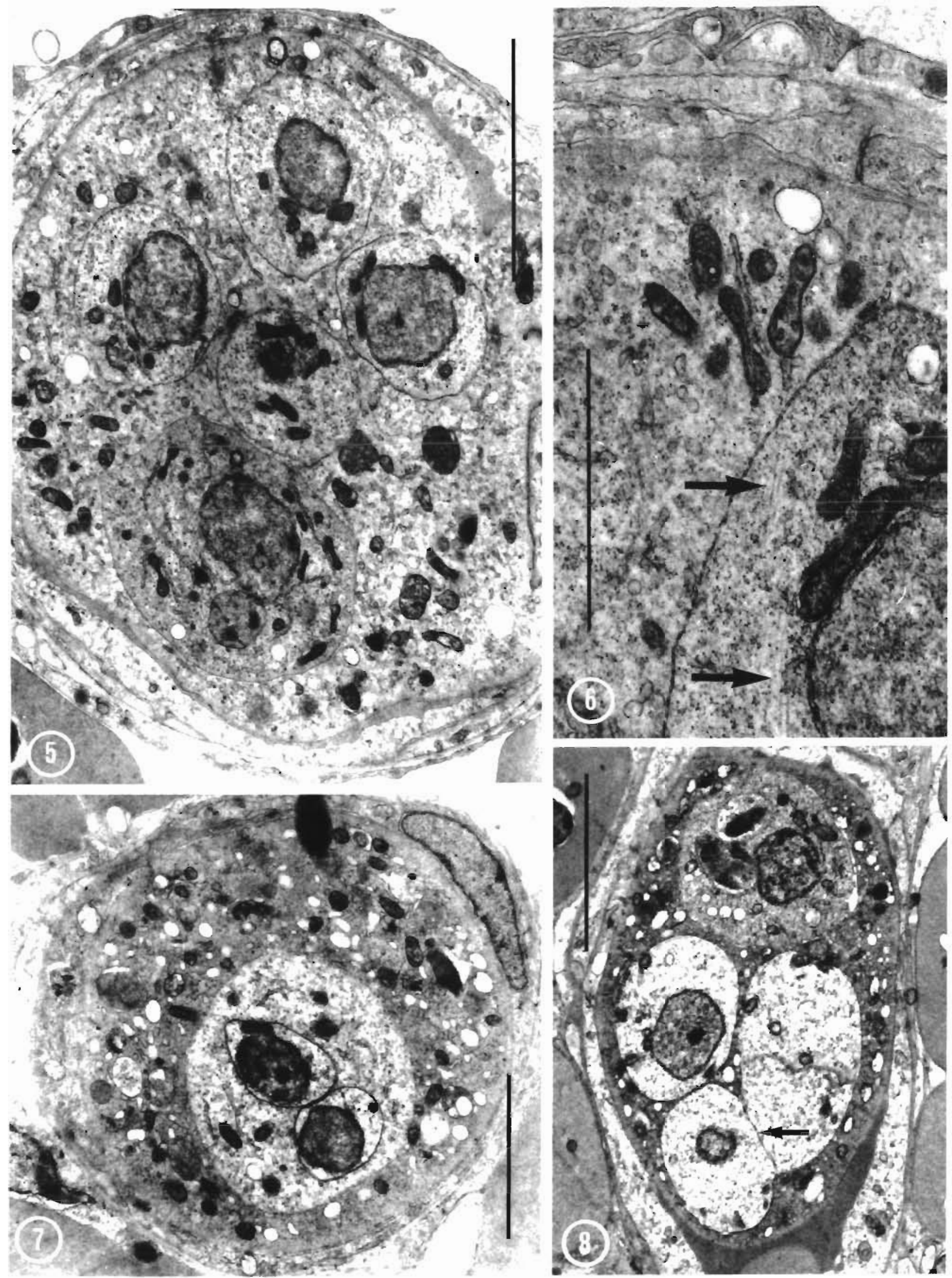

Figs 5 to 8 Myxosporean vegetative stage in Gasterosteus aculeatus Fig. 5. Primary cell with 5 secondary ones; an opaque substance fills the narrow space between the endothelial cell and the surface of the parasite. Bar $=5 \mu \mathrm{m}$. Fig. 6 . Microtubules in the cytoplasm of the secondary cell Bar $=2 \mu \mathrm{m}$. Fig. 7. A primary cell with 1 secondary cell containing 2 small tertiary cells. Bar $=$ $5 \mu \mathrm{m}$ Fig. 8. A structure (arrowed) suggesting a developing partition between 2 dividing secondary cells. Bar $=5 \mu \mathrm{m}$ 
or parallel with the sporogonic phase and at a site other than that in which sporogony takes place. It obviously belongs to the developmental cycle of one of the 2 myxosporeans found in the sticklebacks. Thus far, samples in which only one species is present have been few in number (Table 1) and since choroidal rete stages are not present in all infected individuals it is not possible to be sure to which species they belong. No extrasporogonic stages of the genus Myxobilatus have been reported - Molnar (1988) reported only early intracellular trophozoites of $M$. legeri in epithelial cells of the cyprinid renal tubules in which the sporogonic phase took place - but such a possibility in any myxosporean cannot be excluded. Thus unusual early stages of infection with Myxobolus cerebralis were found in subdermal tissues of rainbow trout (Daniels et al. 1976 Markiw 1989). However, Sphaerospora spores have been known, as mentioned in the introduction, to have various extrasporogonic stages. Therefore we feel entitled to assign tentatively our findings to the developmental cycle of $S$. elegans unless future experimental work proves otherwise.

The choroidal and swimbladder rete stages do represent a category different from the known types of extrasporogonic stages of Sphaerospora species. They differ from the bloodstream stages in being immobile and in possibly having a predilection for the choroidal rete; they were not often found in the swimbladder rete. Our limited observations in this respect (Lom unpubl.) show no preference of $S$. renicola bloodstream stages for the choroidal rete in carp. They differ from intracellular stages of $S$. renicola forming nodules in renal tubules of carp (Lom \& Dyková 1985) in not exceeding the level of tertiary cells. There are no essential differences, however, in the cell structure of the rete stages on one side and the bloodstream stages (Lom et al. 1983) and swimbladder stages (Dyková et al. 1990) of $S$. renicola on the other side. Meticulous observation may reveal somewhat smaller quantities of free ribosomes and glycogen granules in rete stages while the latter have more cytoplasmic vacuoles and vesicles. The curious fact that no more than one secondary cell on a section contained a tertiary cell does not necessarily mean that there were no more, since serial sections were not observed. However, in this respect the rete stages also differ from bloodstream and swimbladder stages of $S$. renicola. Rete stages comply with the common organisation of early developmental stages of Myxosporea.

We assume that after they have left the rete, the stages reach the kidney to transform into sporogonic pseudoplasmodia. Supposing that the rete stages do belong to the life cycle of Sphaerospora elegans, the observations on their cell structure do not lend any support to, but neither do they contradict, the assump- tion (Kent \& Hedrick 1986, Feist 1988) that this species may be (one of?) the organism(s) with which PKX, the still enigmatic protozoan agent of proliferative kidney disease of salmonids, is identical.

Acknowledgements. The authors thank Kevin McKenzie for expert assistance with the preparation of EM material. The financial assistance to Dr J. Lom by the Nuffield Foundation and the Royal Society is also gratefully acknowledged.

\section{LITERATURE CITED}

Baska, F., Molnar, K. (1988). Observation on the blood stages of Sphaerospora spp. Myxosporea in cyprinid fishes. Dis. aquat. Org. 5: 23-28

Bucsek, M., Csaba, G. (1981). Ultrastructural observations on a carp blood parasite of uncertain taxonomic position. In Olah, J., Molnar, K., Jeney, Z. (eds.) Fish, pathogens and environment in European polyculture. Proc. Int. Seminar Szarvas, Hungary 1981. Fish. Res. Inst. Szarvas, p. 210-221

Csaba, G. (1976). An unidentifiable extracellular sporozoan parasite from the blood of the carp. Parasitol. Hung. 9: $21-24$

Csaba, G., Kovacs-Gayer, E., Bekesi, L., Bucsek, M., Szakolczai, J., Molnar, K. (1984). Studies into the possible protozoan aetiology of swimbladder inflammation in carp fry J. Fish Dis. 7: 39-56

Daniels, S. B., Herman, R. L., Burke, C. N. (1976). Fine structure of an unidentified protozoan in the epithelium of rainbow trout exposed to water with Myxosoma cerebralis J. Protozool. 23: 402-410

Dyková, I., Lom, J., Korting, W. (1990). Light and electron microscopic observations on the swimbladder stages of Sphaerospora renicola, the parasite of carp Cyprinus carpio. Parasitol. Res. 76: 228-237

Feist, S. W (1988). The stickleback. Gasterosteus aculeatus L. and PKD in salmonids - culprit or innocent bystander? Bull. Eur. Ass. Fish. Pathol. 8: 94-97

Hedrick, R. P., Kent, M. L., Toth, R. J., Morrison, J. K. (1988). Fish infected with Sphaerospora spp. Thélohan (Myxosporea) from waters enzootic for proliferative kidney disease of salmonids. J. Protozool. 35: 13-18

Kent, M. L., Hedrick, R. P. (1986). Development of the PKX myxosporean in rainbow trout Salmo gairdneri. Dis. aquat. Org. 1: 169-182

Kepr, T., Trsová, B. (1989). New findings of myxosporean proliferative stages in the blood of freshwater fish. Vestn. Cesk. Spol. zool. 53: 72

Kovács-Gayer, E., Csaba, G., Bekési, L., Bucsek, M., Szakolczai, J., Molnár, K. (1982). Studies on the protozoan etiology of swimbladder inflammation in common carp fry. Bull. Eur. Ass. Fish Pathol, 2: 22-24

Körting, W. (1982). Protozoan parasites associated with swimbladder inflammation (SBI) in young carp. Bull. Eur. Ass Fish Pathol. 2: 25-28

Lom, J. (1987). Myxosporea: a new look at long-known parasites of fish. Parasitology Today 3: $327-332$

Lom, J., Dyková, I. (1985). Hoferellus cyprini Doflein, 1898 from carp kidney - a well established myxosporean species or a sequence in the developmental cycle of Sphaerospora renicola Dykova and Lom, 1982? Protistologica 21: 195-206

Lom, J., Dyková, I., Feist, S. (1989). Myxosporea-induced 
xenoma formation in pike (Esox lucius L.) renal corpuscles associated with Myxidium lieberkuehni infection. Eur J. Protistol. 24: 271-280

Lom, J., Dyková, I., Pavlasková, M. (1983). 'Unidentified mobile protozoans from the blood of carp and some unsolved problems of myxosporean life cycles. J. Protozool 30: 497-508

Lom, J., Pavlasková, M., Dyková, I. (1985). Notes on kidney-

Responsible Subject Editor: W. Körting, Hannover, Germany infecting species of the genus Sphaerospora Thélohan (Myxosporea), including a new species $S$ gobionis $\mathrm{sp}$ nov., and on myxosporean life cycle stages in the blood of some freshwater fish. J. Fish Dis. 8: 221-232

Markiw, M. E. (1989). Portals of entry for salmonid whirling disease in rainbow trout. Dis. aquat. Org. $6: 7-10$

Molnar, K. (1988). Development of Myxobilatus legeri in cyprinid fishes. Dis. aquat. Org. 4: 181-187

Manuscript first received: January 8, 1991 Revised version accepted: March 15, 1991 